Notes and Comments

\title{
First record of leucism in Megaceryle torquata (Coraciiformes: Alcedinidae) in Pantanal, Brazil
}

\author{
V. D. Silva-Alvesa (D), N. L. Sandera* (D) and O. M. A. Nogueiraa (D) \\ a Universidade do Estado de Mato Grosso - UNEMAT, Centro de Pesquisa de Limnologia, Biodiversidade, Etnobiologia do Pantanal - CELBE, \\ Programa de Pós-graduação em Ciências Ambientais, Cáceres, MT, Brasil
}

Leucism does not have a specific cause, but it can be the result of genetic mutations and metabolic or dietary problems (Bensch et al., 2000; Møller and Mousseau, 2001; Cadena-Ortiz et al., 2015). Leucistic birds show normal pigmentation in other regions, such as beak, eyes and legs, unlike the case of albinism (Van Grouw, 2006). The registration of leucistic birds in natural populations rarely exceeds 1\% (Sage, 1963; Bensch et al., 2000). Among the different types of color change, leucism seems to be the most frequent mutation in birds (Van Grouw, 2006). However, until now there was no confirmed record for the species Ringed Kingfisher, Megaceryle torquata (Linnaeus, 1766).

The Alcedinidae family (Rafinesque, 1815) has two genera and five species in Brazil, with $M$. torquata being the only one of the genera and larger than the others whose distribution ranges from Mexico to Tierra del Fuego, throughout South America (Sick, 1997). Among the species in the family, only one possible case of leucism was recorded for a specimen of Green Kingfisher Chloroceryle americana (Gmelin, 1788), where it presented an atypical plumage (Cadena-Ortiz et al., 2015).

Here, we present the first case of leucism in an adult male of $M$. torquata. The registration took place on October 15th, 2019 at 10:15 am (see Figure 1), where we observed the specimen in riparian vegetation of the São Lourenço river, municipality of Poconé, Mato Grosso, Brazil (1740'26.0"S 5700'57.0"W). However, after the registration date, there was no return on the site, to confirm of specimen persistence in the environment.

The detection of leucistic individuals in a natural environment is considered difficult, because these animals are more visible to predators and, consequently, more easily predated (Møller and Mousseau, 2001). In addition, it has been shown that changes in standard coloration may be able to affect various ecological aspects of species, such as reproduction (Blohowiak and Siegel, 1983; Parker et al., 2003), the acquisition of food and the exploration of the area (Mermoz and Fernández, 1999; Shochat et al., 2004).

The Ringed Kingfisher has sexual dimorphism, the female is bluish-grey chest, a white band below the chest and the rusty belly, and the male is brown belly, blue back and head, white throat and neck (Sick, 1997). The partial leucism mutation was diagnosed because the pigmentation of the eyes and belly was normal, with the tail and upper portion white with bluish spots "normal coloration", indicating that the pigment is produced, but is
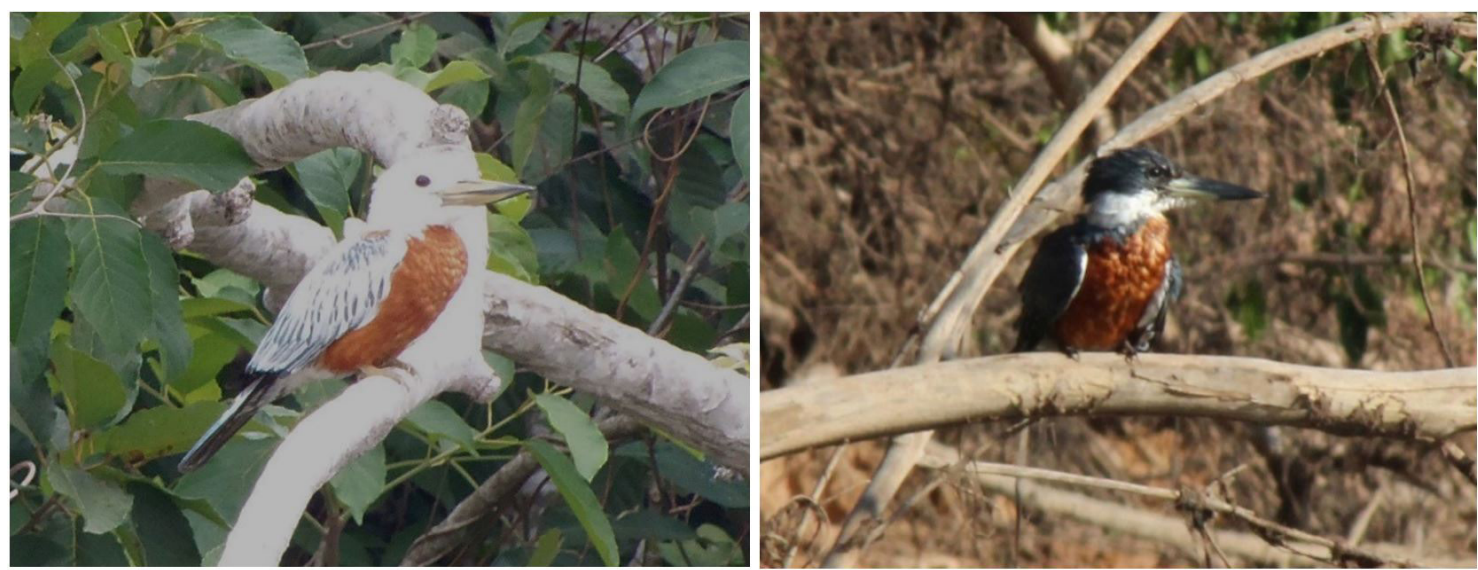

Figure 1. Leucistic individual of Megaceryle torquata recorded on the banks of the São Lourenço river, Poconé - MT. Photo: Diego Velloso do Carmo, 2019. Partial leucistic (left) and normal (rigth) for comparison.

*e-mail: nilosander@gmail.com

Received: April 6, 2020 - Accepted: June 19, 2020

This is an Open Access article distributed under the terms of the Creative Commons Attribution License, which permits unrestricted use, distribution, and reproduction in any medium, provided the original work is properly cited. 
not deposited properly in the feathers (Van Grouw, 2006). In addition, the beak also showed depigmentation "grayish", a characteristic already described in case of partial leucism (Düpont et al., 2014), fact that the term partial or incomplete albinism is inappropriate (Van Grouw, 2006). In the case of C. americana, they observed that the head, neck and wings exhibited a very distinct whitish color, being diagnosed as possibly a case of leucism (Cadena-Ortiz et al., 2015).

Chromatic mutations in birds are difficult to record in nature and describing the behavior of mutants and their variations in the plumage pattern allow the establishment of information for future studies (Van Grouw et al., 2011; Van Grouw, 2012; Corrêa et al., 2017; Santos and Paula, 2020).

\section{Acknowledgements}

The Universidade do Estado de Mato Grosso (UNEMAT), to the Research Project "Corredor Ecológico, Econômico e Cultural do rio Paraguai no contexto das mudanças climáticas no Pantanal" and the Fundação de Amparo à Pesquisa do Estado de Mato Grosso (FAPEMAT) for funding this research (FAPEMAT.0308817/2017). We also thank Diego Velloso do Carmo for providing the leucistic specimen's photography and Ana Paula Dalbem Barbosa for proofreading the English manuscript version.

\section{References}

BENSCH, S., HANSSON, B., HASSELQUIST, D. and NIELSEN, B., 2000. Partial albinism in a semi-isolated population of Great Reed Warblers. Hereditas, vol. 133, no. 2, pp. 167-170. http://dx.doi. org/10.1111/j.1601-5223.2000.t01-1-00167.x. PMid:11338429.

BLOHOWIAK, C.C. and SIEGEL, P.B., 1983. Plumage phenotypes and mate preferences in Japanese quail 2. sexual imprinting. Behavioural Processes, vol. 8, no. 3, pp. 255-275. http://dx.doi. org/10.1016/0376-6357(83)90016-5. PMid:24923714.

CADENA-ORTIZ, H., BAHAMONDE-VINUEZA, D., CISNEROS-HEREDIA, D. and BUITRÓN-JURADO, G., 2015. Alteraciones de coloración en el plumaje de aves silvestres del Ecuador. Avances en Ciencias e Ingenierías, vol. 7, no. 2, pp. B75-B90. http://dx.doi. org/10.18272/aci.v7i2.259.
CORRÊA, L.L.C., HORN, N., BRUCKMANN, C.S. and PETRY, M.V., 2017. Leucism in Vanellus chilensis (Molina, 1872) (Birds: Charadriiformes) in Pampa biome, Southern Brazil. Oecologia Australis, vol. 21, no. 2, pp. 219-221. http://dx.doi.org/10.4257/ oeco.2017.2102.14.

DÜPONT, A., ALCAYAGA, E.L. and RAMOS, R.A., 2014. Leucismo em Ortalis guttata squamata (Galliformes: Cracidae), município de Santa Cruz do Sul, RS, Brasil. Caderno de Pesquisa. Série Biologia, vol. 26, no. 3, pp. 6-13. http://dx.doi.org/10.17058/cp.v26i3.5251.

MERMOZ, M.E. and FERNÁNDEZ, G.J., 1999. Albinismo parcial en el varillero ala amarilla (Agelaius thilius). Nuestras Aves, vol. 40, pp. 20-21.

MøLLER, A.P. and MOUSSEAU, T.A., 2001. Albinism and phenotype of barn swallows (Hirundo Rustica) from chernobyl. Evolution; International Journal of Organic Evolution, vol. 55, no. 10, pp. 2097-2104. http://dx.doi.org/10.1111/j.0014-3820.2001. tb01324.x. PMid:11761068.

PARKER, T.H., STANSBERRY, B.M., BECKER, C.D. and GIPSON, P.S., 2003. Do melanin- or carotenoid-pigmented plumage ornaments signal condition and predict pairing success in the Kentucky Warbler? The Condor, vol. 105, no. 4, pp. 663-671. http://dx.doi. org/10.1093/condor/105.4.663.

SAGE, B.L., 1963. The incidence of albinism and melanism in British birds. British Birds, vol. 56, pp. 409-416.

SANTOS, E.G. and PAULA, W.S., 2020. First record of leucism for the Toco Toucan, Ramphastos toco (Piciformes: ramphastidae). Brazilian Journal of Biology = Revista Brasileira de Biologia, vol. 80, no. 3, pp. 680-681. http://dx.doi.org/10.1590/1519-6984.218532. PMid:31596361.

SHOCHAT, E., LERMAN, S.B., KATTI, M. and LEWIS, D.B., 2004. Linking optimal foraging behavior to bird community structure in an urban-desert landscape: field experiments with artificial food patches. The American Naturalist, vol. 164, no. 2, pp. 232-243. http://dx.doi.org/10.1086/422222. PMid:15278846.

SICK, H., 1997. Ornitologia brasileira. 3. ed. Rio de Janeiro: Nova Fronteira, $862 \mathrm{p}$.

VAN GROUW, H., 2006. Not every white bird is an albino: sense and nonsense about colour aberrations in birds. Dutch Birding, vol. 28, no. 2, pp. 79-89.

VAN GROUW, H., 2012. What colour is that sparrow? A case study: colour aberrations in the house sparrow Passer domesticus. International Studies on Sparrows, vol. 36, no. 1, pp. 30-55. http://dx.doi.org/10.1515/isspar-2015-0012.

VAN GROUW, H., RUSSELL, S. and MERNE, O.J., 2011. Notes on colour aberrations in Common Guillemot Uria aalge and Northern Gannet Morus bassanus. Seabird, vol. 24, pp. 33-41. 